\title{
Ancient Laws and New Canadian Refugee Legislation: Evaluating Bill C-31 IN Light of The Book of DeUteronomy
}

\author{
Mark Glanville
}

\begin{abstract}
Some important innovations within Bill C-31, Protecting Canada's Immigration System Act, run contrary to the biblical ethics espoused in the book of Deuteronomy, from the Judeo-Christian scriptures. Components of Bill C-31-such as mandatory detention, no right of appeal, and a five-year delay for application for permanent residence (all these apply to only certain groups of claimants) - are challenged by the ethics, system of justice, and polity of Deuteronomy. In Deuteronomy, the Hebrew word "ger" ("stranger") occurs twenty-one times, indicating the importance of ethics concerning the stranger for this book. Townships and families in Israel have the responsibility to include the stranger in their agricultural, ritual, and cultural lives. Deuteronomy's ethic towards the stranger is embedded in Israel's own history of being a "stranger" or "refugee."
\end{abstract}

\section{Résumé}

Certaines innovations importantes dans le projet de loi C-31 - la Loi visant à protéger le système d'immigration $d u$ Canada - va à l'encontre de principes éthiques bibliques préconisés dans le livre du Deutéronome des Écritures judéo-chrétiennes. Des composantes du projet de loi C-31 - telles que la détention obligatoire, l'absence de droit d'appel, et le délais de cinq ans pour demander la résidence permanente (composantes s'appliquant seulement à certains groupes de demandeurs d'asile) - sont contredites par l'éthique, le système de justice et la politique du Deutéronome. Dans ce livre biblique, le mot hébreu pour "étranger» apparaît 21 fois, soulignant l'importance de l'éthique du Deutéronome à l'égard de l'étranger. Les établissements et les familles en Israël ont la responsabilité d'intégrer l'étranger dans leur vie agricole, rituelle et culturelle. L'éthique du Deutéronome à l'égard de l'étranger est ancrée dans l'histoire même d'Israël en tant qu'étranger et réfugié.

\section{Introduction}

There has been widespread questioning of Bill C-31, Protecting Canada's Immigration System Act (adopted in 2012), for its alleged violation of human rights protected by the Canadian Charter of Rights and Freedoms and, as Catherine Dauvergne put it, for its failure to maintain Canada's humanitarian tradition.1 But there is also a basis for critique arising from ethical principles grounded in scriptures that are fundamental to many religious communities who have consistently been at the forefront of advocacy on behalf of refugees as well as the sponsorship of refugees. This paper focuses on ethical principles articulated in the Bible, specifically in the book of Deuteronomy: some important innovations within Bill C-31 run contrary to the biblical ethics espoused in this book. Components of Bill C-31-such as mandatory detention, no right of appeal, and a five-year delay for application for permanent residence (all these apply to only certain groups of claimants) are challenged by the ethics, system of justice, and polity of Deuteronomy.

Deuteronomy deals extensively with social practice concerning the "stranger." More will be said below, but for now I note that the term "stranger" in Deuteronomy refers to the vulnerable ethnic other who lives among the Israelites, with some correspondence to our contemporary category "refugee." 2 As I will demonstrate, Israel was to offer hospitality to the stranger, taking responsibility for their economic and social inclusion. 


\section{Summary: Five Aspects of Bill C-31 Which Run Counter to Deuteronomy}

Before we get into a detailed discussion, here is a summary of five aspects of Bill C-31 and the ways in which they run counter to Deuteronomy.

1. Claimants from "designated countries of origin" will have their claim process seriously restricted. Deuteronomy's political vision prohibits those who "make the decisions" from engaging in shrewd and economically efficient practices that disadvantage vulnerable populations (e.g., Deut.17:14-20). ${ }^{3}$

2. Hearings for claimants from "designated countries of origin" will be held within either thirty or forty-five days, which does not give adequate time for preparation. Deuteronomy insists upon a system of "rigorous justice" that goes to great lengths to ensure that justice is done for vulnerable people (e.g., 16:20).

3. Access to the Refugee Appeal Division (RAD) is denied to "irregular arrivals" and to refugees from "designated countries of origin." Deuteronomy insists upon equality in the law courts, especially, and explicitly, for the "stranger" (e.g., 1:16).

4. Those considered to be "irregular arrivals" may not apply for permanent residence for five years and are not able to sponsor family members to come to Canada for over five years. Deuteronomy insists that Israel go to lengths to provide a "home" for strangers in her midst (e.g., 16:11, 14).

5. "Irregular arrivals" will face mandatory detention. This runs afoul of the command to "love the stranger (10:18-19) and laws protecting families (e.g., 5:14, 18; 16:14) and, in Deuteronomy's own terms, amounts to "kidnapping" (24:7).

\section{Worldview and Ethics in Deuteronomy: Radical Hospitality}

The Hebrew word behind the Old Testament word "stranger," "alien," and "sojourner" is (usually) "ger." The noun "ger," in Deuteronomy, describes someone who is both ethnically displaced and economically vulnerable. The circumstances of the "ger" in Deuteronomy may be further clarified as being in a dependant relationship with the Israelites with whom she lives. In Deuteronomy "ger" ("stranger") occurs twenty-one times, indicating the importance of ethics concerning the stranger for this book.

There are two main narrative trajectories, so to speak, that undergird Deuteronomy's ethic toward the stranger. The first is that God has generously given land and its produce to Israel and this gift is to be shared. Ancient Israel's worldview begins with a gift: at the heart of reality is a God of limitless generosity. In turn Israel is to respond with thanksgiving and generosity. These three dimensions-gift, thanksgiving, and generosity/inclusion-are all joyfully displayed at the seasonal harvest festivals that Israel shares at the sanctuary. Israel is commanded:

And you shall rejoice before the Lord your God, you and your son and your daughter, your male servant and your female servant, the Levite who is within your towns, the stranger, the fatherless, and the widow who are among you... (16:11; see also $16: 14 ; 26: 11)$

Thus Deuteronomy's social program can be summarized well with the words of Craig Blomberg: "God owns it all, and wants everybody to be able to enjoy some of it."

The second "story" undergirding Deuteronomy's ethic towards the stranger is Israel's own history of being a "stranger" or "refugee."5 This story begins with the displacement of Israel's fathers, Abraham, Isaac, and Jacob (26:5). It is exemplified with Israel as a "stranger" in Egypt in the time of Jacob and Joseph (e.g., 26:5). When Israel was residing as a stranger in Egypt, Egypt did not offer Israel the hospitality she would have desired, but oppressed her with slavery (e.g., 26:6-7). The Lord her God delivered Israel from Egypt's slavery and gave her laws that would shape a new society in which every person could thrive, as a deliberate response to Egypt's oppression (e.g., 26:8-11). That history is the background for this famous passage, along with many others:

[The Lord your God] executes justice for the fatherless and the widow, and loves the stranger, giving him food and clothing. Love the stranger, therefore, for you were strangers in the land of Egypt. (10:18-19)

In light of these two powerful stories of the Lord's deliverance and provision, it is no surprise that Deuteronomy's ethic concerning the "stranger" is an ethic of radical welcome.

An examination of all the details of Israel's responsibility toward the "stranger" would require a substantial book, so for now I briefly note two aspects of their responsibility: First, as Deuteronomy's laws unfold it becomes apparent that the implications of the command to "love the stranger" include welcoming the stranger into whatever town they might wish to live in (23:15-16). Second, individual families in Israel have the responsibility to include the stranger in their agricultural and cultural lives, including the most joyful events on their calendar: annual journeys to the sanctuary in order to celebrate with feasting and joy $(16: 11,14$; 26:11).

I note at this early point that it may be objected that the modern concept of nationhood is foreign to the Old Testament, and so applying its inclusivist ethics to a modern state such as Canada is invalid. Certainly, in Israel there was not a conception of sovereignty as we have today, and 
Israel's borders were more porous than Canada's are now. Yet there was an understanding that Israel was distinct from other nations (just as Canada is) and there was some concept akin to citizenship for Israelites. Indeed this is implied by the very notion of an outsider or stranger. Furthermore the threat of religious contamination, from people of other nations, is a relentless concern of Deuteronomy, making Deuteronomy's ethics of inclusion for vulnerable people of other ethnicities all the more remarkable.

I stress too at this early point that I do not seek to argue from Deuteronomy that Israel's social and religious borders were utterly porous and that anybody and everybody was welcome-Deuteronomy's concerns are more complex than this. I will demonstrate more narrowly that Deuteronomy has an ethic of inclusion concerned with the vulnerable stranger; for all such people, Israel was to offer a radical welcome.

Let's now examine in more detail the five aspects of Bill C-31 mentioned earlier.

\section{"Designated Country of Origin"}

At the discretion of Canada's Minister for Citizenship and Immigration, certain countries will be categorized as "designated countries of origin." This categorization applies to countries deemed to be safe by the minister or else to countries from which claims have often failed or ended prematurely. Claimants from these countries have their claim process seriously restricted: namely, through reduced claim preparation time for hearings and no right of appeal to the RAD.

On one hand this legislation is certainly efficient: claims deemed less likely to succeed on the basis of country are expedited. A news release from the government of Prime Minister Stephen Harper predicts it will save about \$1.65 billion over five years: “Too many tax dollars are spent on bogus refugees." ${ }^{\circ}$ On the other hand, this legislation may endanger vulnerable people within these countries who are rightly seeking refuge. The danger this legislation poses for such people has been expressed succinctly in the Montreal Gazette: "Safe countries are not necessarily safe for everyone in them."

This law then disadvantages certain refugee groups for the sake of efficiency. As such, it runs counter to Deuteronomy's political vision, which prohibits those who "make the decisions" from prioritizing shrewd and economically efficient practices that disadvantage vulnerable populations. The "law of the King" for example (17:14-20) is a tenaciously egalitarian description of political responsibility that insists the King treat all his fellow Israelites as his "brothers." Any accumulation of wealth that the king might engage in at the expense of "his brothers and sisters" is forbidden and is furthermore characterized, chillingly, "as sending the people 'back to Egypt'." (In the context of the whole of Deuteronomy, the "brothers," to whom the King is responsible, includes the "stranger.") Thus, restricted refugee claim processes for the sake of efficiency runs counter to Deuteronomy.

\section{Preparation Time for Hearings on Claims Is as Short as Thirty Days}

For claimants from "designated countries of origin," hearings on claims are expected to occur within forty-five days for those who lodge their claim upon entry and within thirty days for those who do not, according to background briefing notes issued by Citizenship and Immigration Canada. Those who support foreign nationals in their claims for refugee status explain that this is inadequate time to gather evidence and meet with legal counsel and will hinder a refugee's ability to present their case in the best light possible.

The protective wall around Deuteronomy's security for vulnerable people is fair and reliable recourse to the legal system. Deuteronomy 16 describes the appointment of judges and officers and then exhorts: "You must rigorously pursue justice, that you may live and inherit the land that the Lord your God is giving you" (16:20). The phrase "rigorously pursue justice" may also be translated: "Justice, only justice shall you pursue..." In Deuteronomy, a justice system that rigorously pursues a fair process, especially for vulnerable people, is a crucial safety net that ensures that all people can thrive. It is important to add that the character of "justice" in Deuteronomy is shaped by the two formative narrative trajectories I have detailed above: first, it is a response to the Lord's generous gift of land and its bounty, and second, it is a response to the Lord's delivering Israel from Egypt. Thus, "justice" is especially concerned with protecting the lives and well-being of vulnerable people (rather than protecting the privilege of the King or the wealthy; see 10:17-18; 24:17-18).

In the case of Bill C-31, inadequate time to prepare claims compromises the justice of the refugee claim process and so falls short of the rigor required by Deuteronomy.

\section{Denial of an Effective Appeal for Some Claimants}

The Refugee Appeal Division (RAD) provides an important security net for failed claims. Bill C-31 denies this system of appeal to "irregular arrivals" and to refugees from "designated countries of origin." Denial of appeal to the RAD for certain claimant groups is at odds with Deuteronomy's insistence upon legal equity for all people, including and especially the "stranger." I reiterate here that the term "ger" or "stranger" in Deuteronomy is to be defined as the vulnerable and displaced ethnic other, who is in need of ongoing 
hospitality; legal equity is to apply, especially, to such people. See for example how Moses exhorts Israel's judges:

And I charged your judges at that time, "Hear the cases between your brothers, and judge righteously between a man and his brother or the stranger who is with him. (1:16)

It is striking that the stranger is mentioned in this passage. The stranger gets an explicit mention here, I would think, as this is the category of people most likely to be excluded from just legal process (yes, the stranger was vulnerable in ancient times as well!) The stranger is mentioned in order to ensure equality in the law courts. However Bill C-31 denies access to the RAD for "irregular arrivals" and to refugees from "designated countries of origin," offering these claimants a legal process that no Canadian citizen would think fair should it be applied to them.

\section{A Five-Year Ban on Permanent Residence Applications for "Irregular Arrivals," with Implications for Family Reunification}

Bill C-31 designates certain refugee groups as "irregular arrivals." This designation may be applied to a newly arrived group whose identity is difficult to confirm or to a group whose arrival has involved so-called smuggling. These groups have no right of appeal and are subject to short hearing preparation times, as described above. In addition, should they be accepted as refugees, they may not apply for permanent residence for five years. This means that these refugees are not able to sponsor family members to come to Canada for over five years.

These last two restrictions run against Deuteronomy's insistence that Israel go to lengths to provide a "home" for strangers in her midst. The provision of a home is perhaps exemplified in the seasonal sojourners to the sanctuary described in Deuteronomy. Seasonal sojourns to "the place the Lord will choose" punctuate Israel's calendar with a rhythm of worship and celebration. Yet these celebrations are radically inclusive: Israelite households include the "stranger," orphan, widow, and Levite in their journey and celebration-four groups who are economically vulnerable and often without land themselves. Together with the "stranger" and other vulnerable people, an Israelite household journeys to the sanctuary, worships, and then feasts together with great joy $(16: 11,14,26: 1-11)$. These inclusive harvest festivals are a striking example of the radical hospitality and "home making" for displaced people that Israel is called to.

A five-year delay on application for permanent residence and subsequent delays in sponsoring family members runs counter to this radical hospitality, disrupting Canada's accessibility as a "home" for homeless people.

\section{Mandatory Detention}

"Irregular Arrivals" face mandatory detention under Bill $\mathrm{C}-31$. While detention is not mandatory for children under the age of sixteen, detained families are faced with the decision to send their children into foster care in a foreign country and culture or else to have their children with them in detention. Dr. Meb Rashid of the Christie Refugee Health Clinic in Toronto writes:

As a physician who has had the privilege of working with refugee populations for over ten years, I am deeply concerned about the impact of mandatory detention on the health status of an often already traumatized population... I urge the government to reconsider Bill C31-it will cause tremendous hardship on refugee populations and will be a major impediment to successful integration. ${ }^{8}$

I myself, an Australian citizen, know too well of the well-documented mental illness and high suicide rates among refugees resulting from mandatory detention laws in Australia.

Such an arrangement is simply unthinkable within the ethics of Deuteronomy. First, it runs counter to the right of all people to an equitable social order (4:8). Second, it is an abrogation of the command to "love the sojourner" (which is in turn grounded in the reality that God "loves the sojourner," 10:18-19). Third, it runs counter to Deuteronomy's vision for the shared life of families: families work and rest together (5:15), worship together (12:18), feast together (12:18), remember the saving acts of the Lord together (16:11-12), hear the law together (31:12-13), etc. Fourth, from the range of social practices in Deuteronomy, the practice closest to mandatory detention is, I would think, the forbidden act of kidnapping (24:7, cf. Exodus 21:16).

\section{Concluding Reflections}

In light of these reflections one may reply: yet is it not valid for a nation to pursue national interest? And does not nationhood entail such goals? And might not national interest entail the exclusion of refugees, perhaps for the sake of Canada's wealth or internal stability? I reply that nationhood today, as back then, implies principles about ensuring the security of co-nationals and defending the interests of the nation, but it need not entail the unjust exclusion of others, and Deuteronomy shows that it should not entail such unjust exclusion. Certainly, Canada should protect itself from violence, both internal and external, but it is only an unjustifiably selfish nation-statism that thinks Canada 
has a right to do this in ways that excludes the vulnerable on its doorstep. And it is only a deeply problematic political theory or political theology that seeks to defend such an approach.

How may we appropriate Deuteronomy's ethics of radical welcome? For Jews, Christians, and Muslims, Deuteronomy makes a normative claim upon individuals and upon society, calling for a radical welcome and just process for all strangers who find their way to our gates, for refugees who arrive in any of a variety of ways to Canada. This ancient Near Eastern law code has called society and church to just practices for around three thousand years and it roundly condemns these five aspects of Bill C-31 as unjust.

\section{Notes}

1. "Refugee Rules the End of Canada's Humanitarian Tradition," Toronto Globe and Mail, January 29, 2013, http:// www.theglobeandmail.com/commentary/refugee -rules-the-end-of-canadas-humanitarian-tradition/ article7937115/.

2. So F. A. Spina, "Israelites as Gerim: Sojourners in Social and Historical Context," in The Word of the Lord Shall Go
Forth: Essays in Honor of David Noel Freedman in Celebration of His Sixtieth Birthday, ed. C. L. Meyers and M. O'Connor (Winona Lake, IN: Eisenbrauns, 1983), 322.

3. All biblical citations are from the book of Deuteronomy unless otherwise stated and are taken from the English Standard Version (Wheaton: Crossway Bibles, 2001).

4. Craig Blomberg, Neither Poverty nor Riches: A Biblical Theology of Possessions (Illinois: Apollos, 1999), 241.

5. Nathan MacDonald, Not Bread Alone: The Uses of Food in the Old Testament (Oxford: Oxford University Press, 2008), $93 \mathrm{f}$.

6. "News Release: Harper Government Introduces the Protecting Canada's Immigration System Act," Citizenship and Immigration Canada, http://www.cic.gc.ca/english/ department/media/releases/2012/2012-02-16.asp.

7. S. D. McBride, "Polity of the Covenant People: The Book of Deuteronomy," Interpretation 41(1987): 41.

8. "Collected Comments on Bill C-31," Canadian Council for Refugees, http://ccrweb.ca/fr/node/14505.

Mark Glanville is a PhD candidate with Trinity College, Bristol, UK, residing in Vancouver, British Columbia, Canada. 
(C) Mark Glanville, 2013. This open-access work is licensed under a Creative Commons Attribution-NonCommercial 4.0 International License, which permits use, reproduction and distribution in any medium for non-commercial purposes, provided the original author(s) are credited and the original publication in Refuge: Canada's Journal on Refugees is cited. 